\title{
Review of the monograph: \\ Barai, M.K. (Ed.). (2020). \\ Bangladesh's Economic and Social Progress: From a Basket Case to a Development Model. London, Palgrave Macmillan (Springer Nature Singapore)
}

\author{
Badar Alam Iqbal \\ University of South Africa \\ Preller Street, Muckleneuk Ridge, Pretoria, Republic of South Africa \\ Monarch Business School \\ 1 Flurstrasse, Zug, CH-6332, Swiss Confederation
}

\begin{abstract}
The monograph under review is devoted to a multilateral analysis of the Bangladesh economy and the prospects for its development in the modern world. The book provides an in-depth analysis of the financial and industrial sectors of the economy, industrial policy, the prospects for an innovative economy in Bangladesh.
\end{abstract}

Keywords: Bangladesh, sustainable development, economic growth, new technologies, development scenarios

\section{Introduction}

The book is a comprehensive yet crisp analysis of the trajectory the Bangladesh economy has navigated since its formation. The author has assigned the title "From a Basket Case to a Development Model" to the economic and social progress that the economy has made across the timeline and rightfully so. The book is organised into six parts. The first part introduces the reader to the economic and social accomplishments of Bangladesh in latest years. In doing so, the author makes quick reference of key statistics of the Bangladesh economy. For instance, the chapter begins with stating Bangladesh's momentum in moving " 16 notches up" in becoming the $26^{\text {th }}$ largest economy in the world in the future from the present status of $42^{\text {nd }}$ largest. This stride is an amalgamation of the progress Bangladesh has portrayed on various social and economic indicators. The strides made in literacy, health, poverty rates and economic growth has made an appearance right at the start of the chapter. The chapter tries to bring out the story of the development of Bangladesh economy since its independence in 1971. The turn about made in the economic and social parameters of Bangladesh is something that has puzzled pundits and analysts. From being termed a "poster child for Malthusia" to becoming the largest economy in the LDC category, Bangladesh has 
come a long way in its economic and social story. In 1971 when Bangladesh got independence, it had all the classic characteristics of a developing country viz. illiteracy, high poverty rates, high birth and death rates, lack of good hygiene and sanitation problems, financial problems, etc. to name a few. The journey of Bangladesh economy from this lowest rung to the pedestal is what both amazes and surprises pundits and analysts.

Apart from statistical reflections right at the outset of the chapter, the first chapter serves to achieve multiple objectives. After a brief sketch of the progress in economic and social indicators of Bangladesh, the discussion moves on to a set of competitive theories of development from different time periods of the history. This gives a depth to the theoretical setting of the entire book. Also, the author attempts to give some prospective theories on which Bangladesh's development path could have been based. The discussion of various competing theories aids in placing Bangladesh's trajectory into one or another theoretical framework. It also helps in telling if Bangladesh has navigated a development path totally different from those suggested by preexisting development theories. The book treads on various aspects of the Bangladesh economy. Within the six parts of the book is a coming together of various facets of life in the Bangladesh economy. The first part brings out the development model of the Bangladesh economy. The second part designs the moulds in which the Bangladesh economy thrives. For instance, the second part of the book visits the features of the Bangladesh economy which garners the country's development a unique look. The second part rejoices in the interspersed nature of economic and social development of Bangladesh economy. The third part of the book keeps the door ajar for the reader to have a look on the financial sector of the Bangladesh economy. This is done by substantial evidence in the chapters on the porous nature of finance in the Bangladesh economy. The seating of remittances in the overall development of Bangladesh economy makes the third part of the book particularly gripping. Other developing countries of the sub-continent could draw lessons from the Bangladesh economy on wheeling remittances in development works and programs. The fourth part of the book publishes detailed role of different economic sectors in the development trajectory of the Bangladesh economy. The garment industry of Bangladesh has drawn global fame over the years. Its role in establishing Bangladesh as a manufacturing hub of South-Asia is emphasised at length. The fourth part of the book gives substance on the rural economy as well apart from the vital role of garment manufacturing in the development boom of Bangladesh. A futuristic glance on the engineering sector becomes an engaging chapter of the fourth part of the book. The fifth part of the book manoeuvres the play of government and civil society especially NGOs in building the path of development Bangladesh now waltzes on. The important role of NGOs in development of Bangladesh has been portrayed since the country achieved liberation in 1971. Then onwards, the activities and operations of NGOs have largely diversified and have intensified from mere rehabilitation to those assisting in economic, social and political development as well. It is this transition in the NGOs activities which is discussed extensively in this part of the book. Beyond acknowledging NGOs part in the development of Bangladesh, there follows a deep look in the "form" the NGO sector adds to the development in Bangladesh. A special role of NGOs in the Rohingya crisis of 2017 builds the vocal chords of this part of the book. This part of the book provides answers to the puzzled and 
perplexed pundits in the light of the government binding approaches. The sixth part of the book concludes the discussion along with the challenges to the present development trajectory. While Bangladesh relishes on a robust economic growth paralleled with a strong social sector, the delicate governance structure and infrastructural deficit of the Bangladesh economy could jeopardize the hope of a sustainable development path in Bangladesh. Also, the income divide and human capital deprivation also risks losing the strong gait the Bangladesh economy has witnessed over the decades. From the challenges, the way forward needs to be chalked out where both physical, geographical, and economic factors should be given proper mileage and attention.

\section{Purpose}

The purpose of the book is three-fold. The first purpose is to bring out the factors at the back of the stupendous development performance the economy of Bangladesh has portrayed over the decades. It is to show the onlookers as well as the commentators that this development is not taken place in a "void" in the words of the author. Both the internal and external factors at the heart of the development path treaded by Bangladesh are deciphered in detail organised into several chapters and told through a variety of voices. The second purpose of the book is to make the development case of Bangladesh an anchor for the rest of the world especially the other developing or less developed economies. Bangladesh, by its developmental progress, can now act as an anchor to the development strategy of other economies of the third world grappling with the same problems that Bangladesh was once severely clasped in. Though challenges remain for making this development tract a sustainable one, other less developed countries could still draw lessons from the overturn Bangladesh made in its despicable economic and social environs. The third purpose of this endeavour is to provide the academicians across the world a chance to grasp for themselves the successful venture of Bangladesh from a basket case to a development model. This book offers all the stories of Bangladesh's success at one place through a macro lens. Earlier, to see the Bangladesh economic development, academics were required to scramble from crumbs or little pieces of evidence here and there. This book has done the task of connecting the dots to give a complete picture of development in Bangladesh. The book intends to broadcast the development strides Bangladesh has made to a larger audience which in turn could give development economics a new vibrancy. On of the catching purposes of the book is to make the development case of Bangladesh reach far and wide and serve as a beacon of hope for development economics elsewhere. Through its academic purposes, the book could sensitize the developmental problems in the way of less developed economies.

By intending to fulfil the multiple purposes from this endeavour, the book beckons new avenues of opportunities for the challenges on the face of the developing and less developed countries. The macro snapshot of the Bangladesh economy channels a new thought process for difficulties and bottlenecks in sustainable development.

\section{Issues covered}

The book offers an elaborate coverage of multifarious issues. From a macro vantage point, the book encapsulates wide ranging issues. The unfolding of the economic as well as social sector of the Bangladesh economy over the years is well 
taken care of. All of the issues relevant in the present day stature of Bangladesh economy find space in the book. These issues are both related to both production and distribution. The social sector of the country stands apart from those witnessed in its counterpart economies. Thus, the social sector issues and peculiarities are discussed at length over the length and breadth of the book. The following listicle provides the issues that the book envisages to open on.

Poverty and inequality. The book addresses the issue of poverty and inequality for the Bangladesh economy. It is done so in the second chapter. The chapter gives a special reference to the evident scenario in the Bangladesh economy. While poverty incident rates have declined surprisingly well within the time range of 1991-2010, income inequality has climbed up. The rise in income inequality is apparent in the Gini coefficient rising markedly within the period 2010-2016. This predicament is seen to be in line with the 'miracle' witnessed by East Asian economies. Both poverty and income inequality patterns seem to replicate the exact gait it assumed in the case of East Asian economies. This pattern of poverty reduction yet revving income inequality and how it characterizes Bangladesh's 7 percent growth trajectory is what is arduously considered.

Climate change resilient economic growth. Climate change is a common enemy when it comes to all the countries of the global economy. It spares none. It doesn't tell the developed from the developing country. While Bangladesh has been able to be consistent in its 7 percent growth trajectory, the climatic risks are bringing risks to all the progress made so far. At the cusp of devastation from extreme climatic events is not only the lives of millions but also their livelihoods. The rampant climatic events like cyclones in the Bay of Bengal have far reaching consequences for agriculture and food security in the Bangladesh economy. The book brings out the ramifications of climate change in the third chapter. The devastating impact of climate change on water availability and access is something of a great concern for the South Asian countries. The access to clean drinking water stands to be hampered if extreme climatic events become more rampant and uncontrollable as projected by the IPCC. The issue of rising greenhouse gas emissions is also taken up. With global warming hitting a higher note, the outbreak of diseases like Malaria, Dengue, skin problems, etc. is likely to aggravate in Bangladesh. The wide-ranging consequences of climate change are dealt with precision and care. The need for a climate change insulated economic growth path is identified through these pressing issues the book covers. This path is identified to be of the sort of a green growth where "equity and justice" are ensured and a conscious effort is paid to minimising environmental degradation from all the economic and industrial activity amassing the economic growth.

Education and health sectors. The book delivers substantially on the progress made in social sector of Bangladesh of which education and health sectors are well noticeable. In pursuing the education sector, the book contradicts the understanding of development economists about the payback of education to the society. A considerable emphasis is given on the role of educational attainment in the progress and good performance of the health sector. The issue is taken up and explored extensively. The vitality of education is approached such that it is perceived that education induces a kind of human development that enables 
the achievement of other "entitlement" such as health. Going past the conventional wisdom of development economists in relation to education and health sectors, the book situates the triumvirate of education, health and life expectancy into a model that best explains the trio's role in creating the type of "social capital" that assures the development path to be sustainable.

Financial sector. The book covers the entire working and role of financial sector of Bangladesh which over the years has evolved immensely. Though the influential role that the financial sector plays in the growth trajectory of a country is a lot focused upon by earlier efforts, the book stands out in bringing the exemplary evidence specific to Bangladesh economy. The book speaks on the overall structure of the financial sector in the Bangladesh economy. A complete picture of financial sector in Bangladesh gives due recognition to both banking as well non-banking financial institutions. The story of evolution of the banking and non-banking sector of Bangladesh since its independence is precisely given. Also, the financial bond and equity markets are given due mileage in the take-off of Bangladesh's financial sector. The structural and policy regulations that have re-organized the financial sector from its independence form is widely discussed. Finally, the book provides empirical guidance in the matter by estimating the role of financial sector in economic growth of Bangladesh from 1974 to 2017.

Financial inclusion. The book covers financial inclusion in the Bangladesh economy in the second part. The role of financial inclusion in providing a sustainable trajectory to the economic growth is undeniable. The Bangladesh's contours of financial inclusion are clearly defined and explained and it is along these lines that empirical evidence is furnished. The book covers the empirical scrutiny for financial inclusion in Bangladesh and its impact on economic development for a time frame of 2004-2017. This effort gives the book quite an interesting angle as Bangladesh appears to be the only country in the entire South Asian region to be mooting the formalization of financial inclusion.

Foreign remittances. The book, in its third part makes an important contribution to the development related impacts of migration from the remittances it generates. The case of Bangladesh has been quite elemental in altering the global composition of migration. The increasing international migration of Bangladesh's semi-skilled and unskilled workers since 2000s has generated herculean amounts of foreign remittances. Most of this international migration is to the Middle East and also within Asia. Certain economic events have created this spur in international migration which in turn has catapulted the structure of foreign remittances. The book covers the change in composition of remittances over the years as globalisation pounded the world economy. The developmental impacts of the surge in remittances is also covered in the book. Impact assessment methodology lends evidence into the critical role of remittances in the Bangladesh economy.

The primary and industrial sector. The book in its fourth part encompass a comprehensive account of the particular activities in the primary as well as the industrial sectors of Bangladesh economy that add extravagantly to the overall development path of the country. The role of agricultural sector in the developmental progress of Bangladesh is taken into account. Through data on male and 
female employed in agriculture and also the land holdings, the book deciphers that although the population living on agricultural activities has declined, there still is a rise in production of livestock, food and crop. Empirical testing gives further impetus to the discussion on the rural economy and the transition to an industrial or service-based economy. Within the industrial sector, an important mention is of the ready-made garments industry and also light engineering goods industry. The book, in the fourth part gives weightage to these two industries in charting the growth trajectory of Bangladesh. While the growth and importance of the ready-made garments industry is well celebrated as a driver of growth in Bangladesh, the same emphasis is not given on the light engineering sector which is an important substituting industry. The prospects of the light engineering sector are promising and the book gives the details for the same.

The coverage of the book is not limited to a specific sector or issue and it steps up to encompass all the economic and social dimensions of the Bangladesh economy. By reflecting on sector specific needs and challenges, the book makes a huge contribution to the available literature on Bangladesh economy. The book can serve policy makers as well academicians all over the globe in taking cue from the development experience of Bangladesh.

\section{Strengths}

The book deliberates effort on various challenges and obstacles on the way ahead for Bangladesh economy. The book emerges quite diversified in the topics and issues it deals with. Apart from the theoretical understanding, each and every issue is dealt with facts and figures. The evidence on the issues is coupled with empirical findings. This lends an authenticity and accuracy to the issues the book speaks on. The availability of meaningful data on each issue that the book encompasses gives the reader an easy and quick grasp over the issues. The intricacies of the Bangladesh economy are presented in a very pleasant manner. Wherever necessary, a prompt comparison is drawn with the neighbouring South Asian economies like India which provides an anchor to readers motivated in having an insight on comparative analysis of development paths in both the countries. At certain point, there is a relative drawn with the neighbouring state of West Bengal too. The navigation between chapters is quite easy and follows a smooth tread. The introductory chapter sets an excellent precedent for the rest of the chapters to follow. The chapters run in the exact fashion things have turned up in the introductory chapter. The introduction of the book is both a quick snapshot as well as an elaborate description of the doings of Bangladesh economy in its economic, social and political sphere. The developmental context of the trajectory observed by Bangladesh is placed in respect with certain popularised development theories. By giving a brief overview of the earlier development theories, the introductory chapter gives the reader an effortless hold over the eminent theories and also gives the reader the freedom to think the development path of Bangladesh from different perspectives in the light of existing theories. By the end of the book, the organisation of the book hands the audience a firm grip over the functioning of the various sectors of Bangladesh economy and an explanation to the development miracle that so puzzles the analysts and commentators. 


\section{Weaknesses and limitations}

The book cleverly digs up the issues that have fashioned the development path over the years from the year Bangladesh achieved independence. However, two issues that were largely overlooked in all of the discussion are that of disability and labour rights. There must be a proper mechanism to enforce labour rights in Bangladesh. For this purpose, academics should come forward and recommend policy interventions. The disable population in Bangladesh should also be taken into the ambit when issues like food security, hunger, malnutrition, health and education are considered. These issues need a mention in the overall picture of Bangladesh economy. Without this, the picture appears incomplete. While the achievement of economic growth that is resilient to climatic shocks is discussed with much labour, there must also be emphasis on reducing GHG emissions.

\section{Conclusion: lesson to other countries}

There are a variety of lessons that other developing and least developed countries could draw from Bangladesh's example. Despite overwhelming population and decrepit social conditions in the beginning of its journey, Bangladesh has reached a pedestal and this could invigorate interest in other countries of the similar order to take cue from the working of Government, NGOs, institutions and people for the betterment of the country. India could learn to expand its export competitiveness from Bangladesh. The strides in export have leveraged Bangladesh to increase its economic growth. India should improve on its manufacturing as well as export competitiveness from taking cue from Bangladesh. The female labour force participation rate is impressive in Bangladesh. This ensures gender equality in the country. This must act as a lesson for other countries to work up their labour force participation rates especially for women. The micro-finance institutions and self-help groups have steered the transition of Bangladesh to a success story. Other countries should propel these networks and increasing their reach to the deprived regions. Better finance and credit conditions would certainly provide an impetus to development levels of other South Asian economies as well.

\section{References}

Barai, M.K. (Ed.) (2020). Bangladesh's Economic and Social Progress: From a Basket Case to a Development Model. London, Palgrave Macmillan (Springer Nature Singapore).

\section{Article history:}

Received: 20 June 2020

Accepted: 31 August 2020

\section{For citation:}

Iqbal, B.A. (2020). Review of the monograph: Barai, M.K. (Ed.). (2020). Bangladesh's Economic and Social Progress: From a Basket Case to a Development Model. London, Palgrave Macmillan (Springer Nature Singapore). RUDN Journal of Economics, 28(4), 858-865. http://dx.doi.org/10.22363/2313-2329-2020-28-4-858-865 
Bio note:

Badar Alam Iqbal, Professor Extraordinaries of the College of Graduate Studies of the University of South Africa; Adjunct Professor of the Faculty of Economics and Finance of the Monarch Business School. E-mail: badar.iqbal@fulbrightmail.org; dr.iqbal@monarchuniversity.ch

Рецензия на монографию:

\title{
Bangladesh's economic and social progress: from a basket case to a development model / ed. by M.K. Barai. London: Palgrave Macmillan (Springer Nature Singapore), 2020. 463 p.
}

\author{
Б.А. Икбал \\ Университет Южной Африки \\ Южно-Африканская Республика, Претория, Muckleneuk Ridge, Preller Street \\ Бизнес-школа «Монарх» \\ Швейцарская Конфедерачия, СН-6332, Цуг, Флурштрассе, 1
}

\begin{abstract}
Аннотация. Рецензируемая монография посвящена многостороннему анализу экономики Бангладеш и перспективам ее развития в современном мире. В книге дается углубленный анализ финансового и промышленного секторов экономики, промышленной политики, перспектив инновационной экономики Бангладеш.
\end{abstract}

Ключевые слова: Бангладеш, устойчивое развитие, экономический рост, новые технологии, сценарии развития

\section{История статьи:}

Дата поступления: 20 июня 2020 г.

Дата принятия к печати: 31 августа 2020 г.

\section{Для цитирования:}

Iqbal B.A. Review of the monograph: Barai, M.K. (Ed.). (2020). Bangladesh's Economic and Social Progress: From a Basket Case to a Development Model. London, Palgrave Macmillan (Springer Nature Singapore) // Вестник Российского университета дружбы народов. Серия: Экономика. 2020. Т. 28. № 4. C. 858-865. http://dx.doi.org/10.22363/ 2313-2329-2020-28-4-858-865

\section{Сведения об авторе:}

Икбал Бадар Алам, доктор наук, профессор Колледжа аспирантуры Университета Южной Африки; профессор факультета экономики и финансов бизнес-школы «Монарх».E-mail: badar.iqbal@fulbrightmail.org; dr.iqbal@monarch-university.ch 